\title{
Enzymatic Inactivation of Bradykinin by Rat Brain Neuronal Perikarya
}

\author{
Elaine A. DelBel, ${ }^{1}$ Afonso P. Padovan, ${ }^{1}$ Gilberto J. \\ Padovan, ${ }^{1}$ Otto Z. Sellinger, ${ }^{2}$ and Antonio R. Martins ${ }^{1,3}$
}

Received March 1, 1989; accepted March 5, 1989

KEY WORDS: isolated nuerons; bradykinin inactivation; thiol-endopeptidase; endopeptidase 24.11; angiotensin-converting enzyme; prolyl endopeptidase.

\section{SUMMARY}

1. Bradykinin (Bk; $\mathrm{Arg}^{1}-\mathrm{Pro}^{2}-\mathrm{Pro}^{3}-\mathrm{Gly}^{4}-\mathrm{Phe}^{5}-\mathrm{Ser}^{6}-\mathrm{Pro}^{7}-\mathrm{Phe}^{8}-\mathrm{Arg}^{8}$ ) inactivation by bulk isolated neurons from rat brain is described. body).

2. Bk is rapidly inactivated by neuronal perikarya $(4.2 \pm 0.6 \mathrm{fmol} / \mathrm{min} / \mathrm{cell}$

3. Sites of inactivating cleavages, determined by a kininase bioassay combined with a time-course Bk-product analysis, were the $\mathrm{Phe}^{5}-\mathrm{Ser}^{6}$, Pro $^{7}-\mathrm{Phe}^{8}$, Gly ${ }^{4}-\mathrm{Phe}^{5}$, and $\mathrm{Pro}^{3}-\mathrm{Gly}^{4}$ peptide bonds. The cleavage of the $\mathrm{Phe}^{5}-\mathrm{Ser}^{6}$ bond inactivated $\mathrm{Bk}$ at least five fold faster than the other observed cleavages.

4. Inactivating peptidases were identified by the effect of inhibitors on $\mathrm{Bk}$-product formation. The $\mathrm{Phe}^{5}-\mathrm{Ser}^{6}$ bond cleavage is attributed mainly to a calcium-activated thiol-endopeptidase, a predominantly soluble enzyme which did not behave as a metalloenzyme upon dialysis and was strongly inhibited by $N$-[1(R,S)-carboyx-2-phenylethyl]-Ala-Ala-Phe- $p$-aminobenzoate and endo-

\footnotetext{
${ }^{1}$ Departamento de Farmacologia e Laboratório de Química de Proteinas, Faculdade de Medicina de Ribeirão Prêto, Universidade de São Paulo, Ribeirão Prêto, São Paulo, Brasil.

${ }^{2}$ Mental Health Research Institute, University of Michigan, Ann Arbor, Michigan 48109.

${ }^{3}$ To whom correspondence should be addressed at Departamento de Farmacologia, Faculdade de Medicina de Ribeirão Prêto, Universitade de São Paulo, 14049-Ribeirão Prêto, SP, Brasil.

${ }^{4}$ Abbreviations used: ACE, angiotensin-I converting enzyme; AMC, 7-amino-4-methyl-coumarin; antiserum, rat brain endo-oligopeptidase $\mathrm{A}$ antiserum; $\mathrm{Bk}$, bradykinin $\mathrm{cF}, N-[1(R, S)$-carboxy-2phenylethyl]; CNS, central nervous system; DFP, diisopropylfluorophosphate; DTT, dithiothreitol; MCA, 4-methyl-coumarinyl-7-amide; MK 422, $N$-[(S)-1-carboxy-3-phenylpropyl]-L-Ala-L-Pro; $\mathrm{N}$ suc, $N$-succinyl; pAB, $p$-aminobenzoate; PCMB, $p$-mercuribenzoate; PE, prolyl endopeptidase; $\mathrm{Z}$, $N$-benzyloxycarbonyl.
} 
oligopeptidase A antiserum. Thus, neuronal perikarya thiol-endopeptidase seems to differ from endo-oligopeptidase $A$ and endopeptidase 24.15.

5. Endopeptidase 24.11 cleaves Bk at the Gly ${ }^{4}-\mathrm{Phe}^{5}$ and, to a larger extent, at the $\mathrm{Pro}^{7}-\mathrm{Phe}^{8}$ bond. The latter bond is also cleaved by angiotensin-converting enzyme (ACE) and prolyl endopeptidase (PE). PE also hydrolyzes $\mathrm{Bk}$ at the Pro $^{3}-$ Gly $^{4}$ bond.

6. Secondary processing of $\mathrm{Bk}$ inactivation products occurs by (1) a rapid cleavage of $\mathrm{Ser}^{6}-\mathrm{Pro}^{7}-\mathrm{Phe}^{8}-\mathrm{Arg}^{8}$ at the $\mathrm{Pro}^{7}-\mathrm{Phe}^{8}$ bond by endopeptidase 24.11, 3820ACE, and PE; (2) a bestatin-sensitive breakdown of $\mathrm{Phe}^{8}-\mathrm{Arg}^{9}$; and (3) conversion of $\mathrm{Arg}^{1}-\mathrm{Pro}^{7}$ to $\mathrm{Arg}^{1}-\mathrm{Phe}^{5}$, of $\mathrm{Gly}^{4}-\mathrm{Arg}^{9}$ to both $\mathrm{Gly}^{4}-\mathrm{Pro}^{7}$ and $\mathrm{Ser}^{6}-\mathrm{Arg}^{9}$, and of $\mathrm{Phe}^{5}-\mathrm{Arg}^{9}$ to $\mathrm{Ser}^{6}-\mathrm{Arg}^{9}$, $\mathrm{Phe}^{8}-\mathrm{Arg}^{9}$, and $\mathrm{Ser}^{6}-\mathrm{Pro}^{7}$, by unidentified peptidases.

7. A model for the enzymatic inactivation of bradykinin by rat brain neuronal perikarya is proposed.

\section{INTRODUCTION}

Bradykinin $(\mathrm{Bk})^{4}$ has been suggested to play a role as a neuromodulator and/or neurotransmitter in the CNS (Snyder, 1980; Kariya et al., 1985) on the basis of several lines of evidence, such as biological activity, localization and distribution, and interaction with a specific receptor. Moreover, all the components of a kallikrein-kinin system, which include kallikrein (Chao et al., 1983), kininogen (Shikimi et al., 1973), kinin-converting (Camargo et al., 1972), and Bkinactivating (Carvalho and Camargo, 1981; cf. Orlowski, 1983) activities, and Bk (Corrêa et al., 1979; Perry and Snyder, 1984; Kariya et al., 1985) have been identified in the mammalian CNS.

$\mathrm{Bk}$ is rapidly inactivated after intracerebroventricular injection (half-life, $26.6 \mathrm{sec}$ ) (Kariya et al., 1982), and its major inactivation mechanism appears to occur through peptide bond cleavage. $\mathrm{Bk}$ neuronal inactivation has been approached in vitro using homogenate preparations, purified peptidases, and cloned cell cultures, among other systems. Regarding the latter system, two cell lines from neural origin (neuro-2a neuroblastoma and $\mathrm{C}_{8}$ glioma clones) were recently employed to study $\mathrm{Bk}$ inactivation (DelBel et al., 1986). Although cell lines can provide useful models to study Bk enzymatic processing, it should be pointed out that they represent a transformed cell system. In this study, we have employed a preparation of bulk isolated neuronal perikarya (Sellinger et al., 1971) from rat brain that is essentially devoid of nonneuronal cell types. This preparation was used to investigate the enzymatic mechanisms of Bk inactivation.

\section{MATERIALS AND METHODS}

\section{Materials}

Bk and its fragments were synthesized by Professors A. C. M. Paiva and L. Juliano, Escola Paulista de Medicina, São Paulo. $\mathrm{N}$-Suc-Gly-Pro-MCA [7-( $\mathrm{N}$ - 
succinyl-glycyl-L-proline)-4-methyl-coumarinamide] and AMC (7-amino-4methyl-coumarin) were from Peptide Institute. Aminex A-5 and Durrum DC-6A resins were from Bio-Rad Laboratories and Durrum Chemical, respectively. All chemicals used for the amino acid analyzer buffer and ninhydrin solutions were from Pierce Chemical. Polyvinylpyrrolidone and bestatin were from General Aniline and Film and Sigma Chemical, respectively. Bovine serum albumin was fraction V from Pentex. MK $422(N-[(S)$-1-carboxy-3-phenylpropyl]-L-Ala-L-Pro) was a gift from Dr. L. J. Greene (Departamento de Farmacologica, Faculdade de Medicina de Ribeirăo Prêto, Universidade de São Paulo). Rat brain endooligopeptidase A antiserum, rabbit IgG fraction (antiserum), was provided by Dr. A. C. M. Camargo, Departamento de Farmacologia, Instituto de Ciências Biomédicas, Universidade de Săo Paulo. cf-A-A-F-pAB $(N-[1(R, S)$-carboxy-2phenylethyl]-L-Ala-L-Ala-L-Phe-p-aminobenzoate) and cF-F-pAB $(N-[1(R, S)$ carboxy-2-phenylethyl]-L-Phe-p-aminobenzoate), as well as Z-Pro-prolinal ( $N$ benzyloxycarbonyl-L-prolyl-prolinal), were provided by Drs. M. Orlowski and S. Wilk (Department of Pharmacology, Mount Sinai School of Medicine of the City University of New York).

\section{Isolation of Neuronal Perikarya}

Neuronal cell bodies were bulk isolated from brains of 18-day-old rats, according to a modification of the procedure of Sellinger et al. (1971). Brains from 13 Wistar rats were placed on an ice-cooled plate and cerebral cortices were dissected. The tissue ( $8.6 \mathrm{~g}$ wet weight) was minced using a razor blade, and $8.1 \mathrm{~g}$ was transferred into $120 \mathrm{ml}$ ice-cold $7.5 \%(\mathrm{w} / \mathrm{v})$ polyvinylpyrrolidone solution containing $1 \%(\mathrm{w} / \mathrm{v})$ bovine serum albumin and $10 \mathrm{mM} \mathrm{CaCl}$ (solution I). The mince was sieved through nylon bolting cloth (Tobler, Ernest and Traber, Elmsford, N.Y.) of 333-, 110- and 73- $\mu \mathrm{m}$ pore size. The volume of the last filtrate was brought to $130 \mathrm{ml}$ with ice-cold solution I. Aliquots $(20 \mathrm{ml})$ of the filtrate were layered on a two-step gradient ( $7 \mathrm{ml} 1.0 \mathrm{M}$ sucrose and $6 \mathrm{ml} 1.75 \mathrm{M}$ sucrose) and centrifuged at $41,000 \mathrm{~g}$ for $30 \mathrm{~min}$ at $4^{\circ} \mathrm{C}$, using a Beckman SW27 rotor. The pellet consisted of purified neuronal perikarya and its purity was assessed by phase-contrast microscopy. In fields comprising more than 50 structured particles, about $90 \%$ were neuronal perikarya. Contaminating structures consisted of bare nuclei and occasional capillary threads. Glial cells were not detected. Neuronal perikarya yield was $(4.4 \pm 0.45) \times 10^{6} \mathrm{cells} / \mathrm{g}$ wet brain cortex (mean $\pm \mathrm{SE}$; $N=5$ ). Each neuronal pellet was either suspended in $2.0 \mathrm{ml} /$ pellet of $0.05 \mathrm{M}$ Tris- $\mathrm{HCl}$ buffer, $\mathrm{pH} 7.5$, containing $0.32 \mathrm{M}$ sucrose, and homogenized using a Potter-Elvehjem homogenizer for use on the same day or rapidly frozen to $-70^{\circ} \mathrm{C}$, stored at $-20^{\circ} \mathrm{C}$, and used within 1 week. Soluble and particulate fractions were prepared by centrifuging the homogenate at $105,000 \mathrm{~g}$ for $1 \mathrm{hr}$ at $4^{\circ} \mathrm{C}$.

\section{Prolyl Endopeptidase Assay}

Prolyl endopeptidase (PE) activity was determined by a modification (Martins et al., 1987) of the procedure of Kato et al. (1980). Initial rates (two or 
three time points) of AMC release were measured by incubating $3.3 \mathrm{mM}$ $N$-suc-Gly-Pro-MCA with the neuronal perikarya homogenate or homogenatederived fraction in $100 \mu \mathrm{l} 0.05 \mathrm{M}$ Tris- $\mathrm{HCl}$ buffer, $\mathrm{pH} 7.5$, containing $0.1 \mathrm{M} \mathrm{NaCl}$ and $2 \mathrm{~m} M$ dithiothreitol (DTT), at $37^{\circ} \mathrm{C}$ for up to $30 \mathrm{~min}$. The homogenate was preincubated with $2 \mathrm{mM}$ DTT at $37^{\circ} \mathrm{C}$ for $5 \mathrm{~min}$ before the addition of substrate. The reaction was stopped by the addition of $2.0 \mathrm{ml} 1.0 \mathrm{M}$ sodium acetate buffer, $\mathrm{pH} 4.2$, per $100 \mu 1$ incubation medium. AMC was determined with an Aminco Model 125 spectrophotofluorometer at $380-\mathrm{nm}$ excitation and $460-\mathrm{nm}$ emission wavelengths on the supernatant $(8300 \mathrm{~g}$ for $10 \mathrm{~min})$ of the acidified incubation medium. Blanks were prepared in the same manner as the incubates, except that 1.0 $M$ sodium acetate buffer, $\mathrm{pH} 4.2$, was added before the homogenate (zero time of reaction). Standard curves $(0.3-3.0 \mathrm{nmol} \mathrm{AMC} / 100 \mu \mathrm{l})$ presented a linear relationship between fluorescence intensity and AMC concentration. Homogenate (up to $50 \mu \mathrm{l}$ ) did not change the standard curve slope. In experiments designed to determine adequate assay conditions for measuring rat brain PE activity, it was shown that $\mathrm{PE}$ specific activity in a brain homogenate was maximal at a $2.5 \mathrm{~m} M$ substrate concentration. AMC release was linearly related to incubation time from 10 to $120 \mathrm{~min}$, for $11-82 \mu \mathrm{g}$ homogenate protein, and PE specific activity was independent of homogenate protein concentration in the above range. All measurements were carried out in duplicate. PE specific activity is expressed as nanomoles of AMC released per minute per milligram of protein.

\section{Kininase Bioassay}

The kininase bioassay (Camargo et al., 1972) measures the rate of hydrolysis of the first peptide bond cleaved in $\mathrm{Bk}$, because the hydrolysis of any peptide bond in the molecule leads to products essentially devoid of spasmogenic activity upon the isolated guinea pig ileum (Suzuki et al., 1969). Initial Bk inactivation rates (two to four time points) were measured incubating $116 \mu M \mathrm{Bk}$ with a neuronal homogenate or homogenate-derived fraction in 250 or $1000 \mu \mathrm{l} 0.05 \mathrm{M}$ Tris- $\mathrm{HCl}$ buffer, $\mathrm{pH} \mathrm{7.5,} \mathrm{containing} 0.1 \mathrm{M} \mathrm{NaCl}$, at $37^{\circ} \mathrm{C}$, for up to $60 \mathrm{~min}$. The reaction was stopped by the addition of a $50-\mu 1$ aliquot of the incubation medium to $0.95 \mathrm{ml} 20 \mathrm{mM} \mathrm{HCl}$. Residual Bk was determined with the isolated guinea pig ileum bathed in $10 \mathrm{ml}$ Tyrode buffer containing $0.14 \mu M$ atropine and $0.17 \mu M$ diphenhydramine at $37^{\circ} \mathrm{C}$. Controls were prepared in the same manner as the incubates, except that $\mathrm{HCl}$ was added before the homogenate (zero time of reaction). Control experiments showed that $\mathrm{Bk}$ was stable in the presence of acidified neuronal homogenate for up to $24 \mathrm{hr}$ and that the incubation of

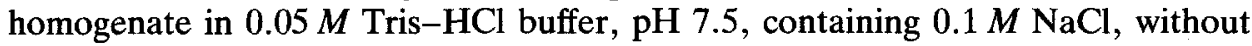
$\mathrm{Bk}$, at $37^{\circ} \mathrm{C}$ for up to $2 \mathrm{hr}$ did not lead to the release of material having spasmogenic activity upon the isolated guinea pig ileum. In experiments designed to determine adequate assay conditions for the measurement of rat brain kininase activity, it was shown that kininase activity was maximal at $100 \mu \mathrm{M} \mathrm{Bk}$. Bk inactivation was linearly related to incubation time from 5 to $180 \mathrm{~min}$, for $30-640 \mu \mathrm{g}$ homogenate protein, and kininase specific activity was independent of 
homogenate protein concentration over a 20 -fold range. All measurements were carried out in duplicate. Kininase specific activity is expressed as nanomoles of Bk inactivated per minute per milligram of protein.

\section{Bradykinin-Product Analysis}

An amino acid analyzer was used to determine $\mathrm{Arg}^{1}-\mathrm{Pro}^{3}, \mathrm{Arg}^{1}-\mathrm{Gly}^{4}$, $\mathrm{Arg}^{1}-\mathrm{Phe}^{5}, \mathrm{Arg}^{1}-\mathrm{Pro}^{7}, \mathrm{Gly}^{4}-\mathrm{Arg}^{9}, \mathrm{Phe}^{5}-\mathrm{Arg}^{9}, \mathrm{Ser}^{6}-\mathrm{Arg}^{9}, \mathrm{Phe}^{8}-\mathrm{Arg}^{9}$, and Gly $^{4}-$ Pro $^{7}$ (Oliveira et al., 1976). Free amino acids were measured by the method of Spackman et al. (1958). The incubation conditions used for Bk-product analysis were similar to those used for the kininase bioassay, unless otherwise stated, and the reactions were stopped by the addition of $1.2 \mathrm{ml} / \mathrm{ml}$ incubation medium of a solution containing $69 \%(\mathrm{v} / \mathrm{v}) 0.2 \mathrm{M}$ sodium citrate, $\mathrm{pH} 2.2,1 \%(\mathrm{v} / \mathrm{v}) 6 \mathrm{M} \mathrm{HCl}$ and $30 \%(\mathrm{v} / \mathrm{v})$ polyethylene glycol 400 . Sample cleanup before amino acid and peptide analysis was carried out by filtration of the hydrolysate supernatant ( $8300 \mathrm{~g}$ for $10 \mathrm{~min}$ ) through a $0.45-\mu \mathrm{m}$ filter (Millipore). The values reported for free amino acids were corected for the blank values obtained by incubating the homogenate or homogenate-derived fractions with or without peptidase inhibitors but without Bk. Control experiments showed that homogenate did not release material that eluted with the elution volume of the peptide standards.

\section{Dialysis}

Dialysis tubing (8/32 Nojax Visking Casing) was freed from contaminating substances according to the procedure of McPhie (1971). Water was purified using a four-cartridge Milli-Q system (Waters). Purified water (resistivity $\geq 10 \mathrm{M} \Omega-\mathrm{cm}$ ) showed the following metal concentration ( $\mathrm{g} /$ liter), measured by atomic absorption spectrophotometry, $<4.5 \times 10^{-8}$, zinc, and $1.1 \times 10^{-7}$, calcium, and was used for the preparation of all solutions. The neuronal perikarya-soluble fraction was treated as described in the legend to Fig. 4.

\section{DNA Determination}

DNA was measured by the procedure of Croft and Luban (1965), using highly polimerized calf thymus DNA (California Corp. Biochemical Research) as the standard.

\section{Protein Determination}

Protein was measured by a modification (Bensadoun and Weinstein, 1976) of the method of Lowry et al. (1951), using bovine serum albumin as the standard. 


\section{RESULTS}

\section{Time Course of Bradykinin-Product Formation}

The only peptide products detected at $10 \mathrm{~min}$ of $\mathrm{Bk}$ inactivation by the neuronal perikarya homogenate (Fig. 1A) were the complementary fragments $\mathrm{Arg}^{1}-\mathrm{Phe}^{5}\left|\mathrm{Ser}^{6}-\mathrm{Arg}^{9}, \mathrm{Arg}^{1}-\mathrm{Pro}^{7}\right| \mathrm{Phe}^{8}-\mathrm{Arg}^{9}$, and $\mathrm{Arg}^{1}-\mathrm{Gly}^{4} \mid \mathrm{Phe}^{5}-\mathrm{Arg}^{9}$. At this time (about $10 \%$ bradykinin inactivation), the stoichiometry of the complementary peptide products $\mathrm{Arg}^{1}-\mathrm{Phe}^{5} \mid \mathrm{Ser}^{6}-\mathrm{Arg}^{8}$ and $\mathrm{Arg}^{1}-\mathrm{Pro}^{7} \mid \mathrm{Phe}^{8}-\mathrm{Arg}^{9}$ was essentially $1: 1$, whereas $\mathrm{Arg}^{1}-\mathrm{Gly}^{4}$ and $\mathrm{Phe}^{5}-\mathrm{Arg}^{9}$ were recovered in the molar proportion 1:0.2. The recovery of the hydrolysis products accounted for $117 \%$ of the $\mathrm{Bk}$ inactivated. These results indicate that isolated neurons hydrolyze Bk at the $\mathrm{Phe}^{5}-\mathrm{Ser}^{6}$, Pro $^{7}-\mathrm{Phe}^{8}$, and $\mathrm{Gly}^{4}-\mathrm{Phe}^{5}$ peptide bonds. The initial rate of $\mathrm{Phe}^{5}-\mathrm{Ser}^{6}$ bond cleavage was about five fold higher than that of the Pro $^{7}-\mathrm{Phe}^{8}$ and $\mathrm{Gly}^{4}-\mathrm{Phe}^{5}$ bonds. At $>10 \%$ Bk inactivation, low amounts $\left(<0.05 \mathrm{~mol} / \mathrm{mol} \mathrm{Bk}\right.$ inactivated) of $\mathrm{Gly}^{4}-\mathrm{Arg}^{9}, \mathrm{Gly}^{4}-\mathrm{Pro}^{7}$, and $\mathrm{Ser}^{6}-\mathrm{Pro}^{7}$ were detected, whereas the low-color yield peptide $\mathrm{Arg}^{1}-\mathrm{Pro}^{3}$, which is complementary to $\mathrm{Gly}^{4}-\mathrm{Arg}^{9}$, was detected only at 40 and $60 \mathrm{~min}$ of incubation $(<0.05 \mathrm{~mol} / \mathrm{mol} \mathrm{Bk}$ inactivated). These results suggest that isolated neurons also hyrolyze $\mathrm{Bk}$ at the $\mathrm{Pro}^{3}-\mathrm{Gly}^{4}$ bond.

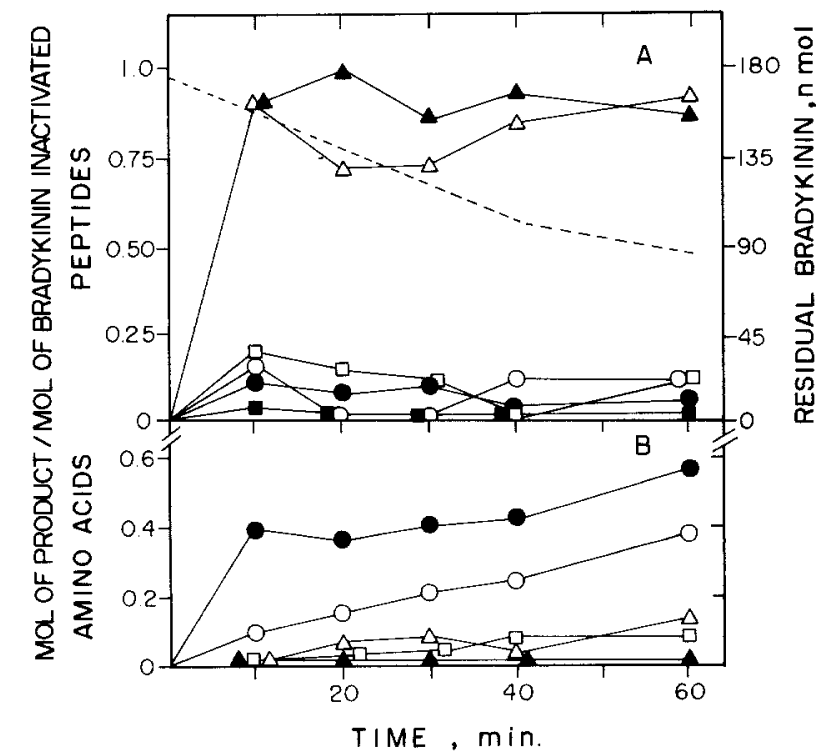

Fig. 1. Time course of $\mathrm{Arg}^{1}-\mathrm{Pro}^{2}-\mathrm{Pro}^{3}-\mathrm{Gly}^{4}-\mathrm{PhC}^{5}-\mathrm{Ser}^{6}-\mathrm{Pro}^{7}-\mathrm{Phe}^{8}-\mathrm{Arg}^{9}$ (bradykinin) hydrolysis by a neuronal perikarya homogenate. Bradykinin $(176 \mu M)$ was incubated with $200 \mu \mathrm{l}$ (21 $\mu \mathrm{g}$ DNA) homogenate in $1.0 \mathrm{ml} 0.05 \mathrm{M}$ Tris- $\mathrm{HCl}$ buffer, $\mathrm{pH} 7.5$, containing $0.1 \mathrm{M} \mathrm{NaCl}$, at $37^{\circ} \mathrm{C}$ for up to $60 \mathrm{~min}$. The reaction was stopped at the indicated times by acidification. Residual bradykinin was determined by bioassay. Bradykinin fragments and amino acids were measured using an amino acid analyzer. (A) Peptides: $\triangle \longrightarrow \triangle$, $\operatorname{Arg}^{1}-\mathrm{Phe}^{5} ; \mathbf{\Lambda}-\mathbf{\Lambda}, \mathrm{Ser}^{6}-\mathrm{Arg}_{9} ; \mathrm{O}-\mathrm{O}, \mathrm{Arg}^{1}-\mathrm{Pro}^{7} ; \mathrm{O}, \mathrm{Phe}^{8}-\mathrm{Arg}^{9} ; \square-\square$,

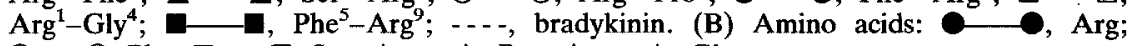

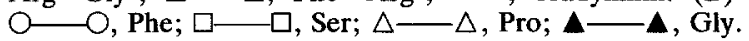


The rates of release of arginine and, to a lesser extent, phenylalanine during Bk inactivation (Fig. 1B) were much higher than those of glycine, serine, and proline. The profile of free amino acids released from $\mathrm{Bk}$ by isolated neurons is similar to that by neuro-2a neuroblastoma but not to that by $C_{8}$ glioma cells (DelBel et al., 1986).

\section{Processing of BK Hydrolysis Products}

The increase in the relative amounts of free amino acids during Bk inactivation (Fig. 1B), concomitantly with a variation of the rate of release and a loss of the 1:1 stoichiometry of the complementary peptide products (Fig. 1A), was due to proteolytic processing of the primary hydrolysis products, possibly by endopeptidases and exopeptidases. Indeed, Table I shows that, in addition to the release of free amino acids, isolated neurons catalyzed the conversion of some primary inactivation products into shorter-chain primary and secondary peptide products. Thus, $\mathrm{Arg}^{1}-\mathrm{Pro}^{7}$ was extensively degraded to $\mathrm{Arg}^{1}-\mathrm{Phe}^{5}$ and, to a lesser extent, to $\mathrm{Ser}^{6}-\mathrm{Pro}^{7}$ and $\mathrm{Gly}^{4}-\mathrm{Pro}^{7}$. The major peptide fragments formed from $\mathrm{Gly}^{4}-\mathrm{Arg}^{9}$ were $\mathrm{Ser}^{6}-\mathrm{Arg}^{9}$ and $\mathrm{Gly}^{4}-\mathrm{Pro}^{7}$, and that from $\mathrm{Phe}^{5}-\mathrm{Arg}^{9}$ was $\mathrm{Ser}^{6}-\mathrm{Arg}^{9} . \mathrm{Ser}^{6}-\mathrm{Arg}^{9}$ and $\mathrm{Phe}^{8}-\mathrm{Arg}^{9}$ were almost completely degraded to free amino acids. At incubation times shorter than $30 \mathrm{~min}$, in addition to free amino acids, $\mathrm{Ser}^{6}-\mathrm{Pro}^{7}$ and $\mathrm{Phe}^{8}-\mathrm{Arg}^{9}$ were released from $\mathrm{Ser}^{6}-\mathrm{Arg}^{9}$ by neuronal perikarya homogenate (data not shown), indicating that the homogenate hydrolyzes the Pro-Phe bond of Ser-Pro-Phe-Arg. In general, the N-terminal products of $\mathrm{Bk}$ inactivation were more resistant to degradation than the C-terminal fragments, possibly due to their Pro-Pro moiety.

\section{Effect of Peptidase Inhibitors on Bk Processing}

Table II shows that the metal chelator 1,10-phenanthroline exhibited a concentration-dependent inhibition of kininase activity, which was $93 \%$ inhibited by $1 \mathrm{~m} M$ chelator. In contrast, the other chelators used exerted either a slight (1 $\mathrm{m} M$ 8-hydroxyquinoline) or no (1 $\mathrm{m} M$ EDTA and $1 \mathrm{~m} M$ EGTA) inhibitory effect on kininase activity. PE activity was affected in the same manner as kininase activity by metal chelators. DTT (up to $2 \mathrm{~m} M$ ) did not appreciably affect kininase activity, while it slightly activated PE activity. Both activities were strongly inhibited by $1 \mathrm{mM}$ PCMB. The serine protease inhibitor diisopropylfluorophosphate (DFP; $0.2 \mathrm{mM}$ ) inhibited 7 and 99\% kininase and PE activities, respectively. cF-Ala-Ala-Phe-pAB, an inhibitor of endopeptidase 24.15 (Chu and Orlowski, 1984), presented a concentration-dependent inhibition of kininase activity (data not shown), which was $90 \%$ inhibited by $1 \mathrm{~m} M$ inhibitor. Maximal inhibition $(75 \%)$ of kininase activity by antiserum was attained at $16 \mu \mathrm{l}$ antiserum $/ \mathrm{ml}$ incubation medium. Z-Pro-prolinal $(10 \mu M)$, a PE inhibitor (Wilk and Orlowski, 1983), inhibited 98\% neuronal perikarya PE but did not appreciably affect kininase activity. Bestatin $(50 \mu M)$, an aminopeptidase inhibitor, did not affect kininase activity.

Table III shows that 1,10-phenanthroline exhibited a concentrationdependent inhibitory effect on the release of the complementary peptide products 


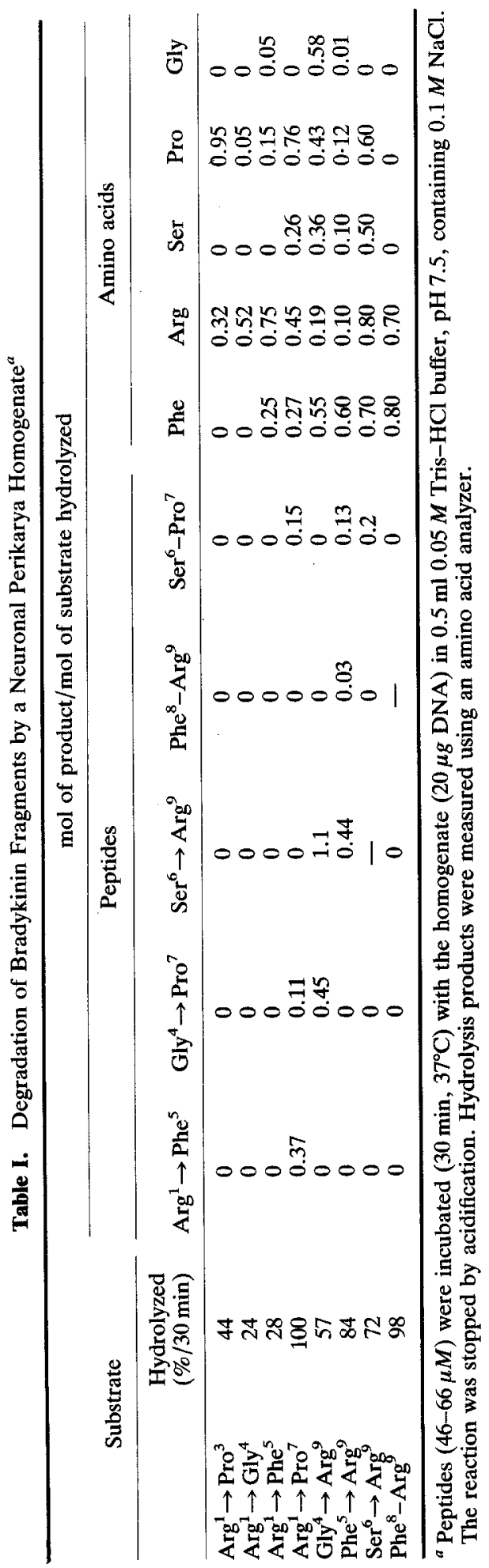


Table II. Effect of Peptidase Inhibitors on Neuronal Perikarya Kininase and Prolyl Endopeptidase Activities ${ }^{a}$

\begin{tabular}{lcc}
\hline \multicolumn{1}{c}{ Inhibitor } & $\begin{array}{c}\text { Kininase activity } \\
(\%)\end{array}$ & $\begin{array}{c}\text { PE activity } \\
(\%)\end{array}$ \\
\hline None & 100 & 100 \\
$0.1 \mathrm{~m} M$ 1,10-phenanthroline & 62 & nd \\
$1.0 \mathrm{~m} M$ 1,10-phenanthroline & 7 & 20 \\
$0.1 \mathrm{~m} M$ 8-hydroxyquinoline & 106 & 106 \\
$1.0 \mathrm{~m} M$ 8-hydroxyquinoline & 80 & 80 \\
$1.0 \mathrm{~m} M$ EDTA & 103 & 107 \\
$1.0 \mathrm{~m} M$ EGTA & 103 & 106 \\
$2.0 \mathrm{~m} M$ dithiothreitol & 110 & 125 \\
$1.0 \mathrm{~m} M$ PCMB & 13 & 2 \\
$0.2 \mathrm{~m} M$ DFP & 93 & 1 \\
$1.0 \mathrm{~m} M$ cF-Ala-Ala-Phe-pAB & 10 & nd \\
$8 \mu 1$ antiserum & 25 & nd \\
$10 \mu M$ Z-Pro-prolinal & 97 & 2 \\
$50 \mu M$ bestatin & 107 & nd \\
\hline
\end{tabular}

${ }^{a}$ The homogenate was preincubated $\left(15 \mathrm{~min}, 37^{\circ} \mathrm{C}\right)$ with or without (control) inhibitor in $0.5 \mathrm{ml} 0.05 \mathrm{M}$ Tris-HCl buffer, $\mathrm{pH} 7.5$, containing $0.1 \mathrm{M} \mathrm{NaCl}$, and incubation (up to $30 \mathrm{~min}, 37^{\circ} \mathrm{C}$ ) was started by the addition of either $116 \mu M$ bradykinin (kininase assay) or $3.3 \mathrm{~m} M N$-suc-Gly-Pro-MCA (PE assay). The incubations were stopped by acidification. Kininase and PE activities were determined by bioassay and fluorimetry, respectively. The average values of four (kininase) and two (PE) determinations, which differed by $20 \%$ or less and $6 \%$ or less, respectively, are reported. Antiserum, endo-oligopeptidase A antiserum; nd, not determined.

$\operatorname{Arg}^{1}-$ Phe $^{5} \mid$ Ser $^{6}-$ Arg $^{9}$ and $\operatorname{Arg}^{1}-$ Pro $^{7} \mid$ Phe $^{8}-$ Arg $^{9}$ and of Ser $^{6}-$ Pro $^{7}$ and free amino acids from BK. The formation of peptide products was essentially abolished by $1 \mathrm{~m} M 1,10$-phenanthroline. EDTA $(1.0 \mathrm{~m} M)$ and DFP $(0.2 \mathrm{~m} M)$ did not inhibit the formation of $\mathrm{Arg}^{1}-\mathrm{Phe}^{5} \mid \mathrm{Ser}^{6}-\mathrm{Arg}^{9}$ but partially blocked that of $\mathrm{Arg}^{1}-\mathrm{Pro}^{7} \mid \mathrm{Phe}^{8}-\mathrm{Arg}^{9}, \mathrm{Ser}^{6}-\mathrm{Pro}^{7}$, and free amino acids. The formation of $\operatorname{Arg}^{1}-$ Phe $^{5} \mid$ Ser $^{6}-$ Arg $^{9}$ was essentially abolished by $0.1 \mathrm{mM}$ PCMB, while the release of $\mathrm{Arg}^{1}-\mathrm{Pro}^{7}$ was about 2.5-fold increased and that of $\mathrm{Phe}^{8}-\mathrm{Arg}^{9}$, $\mathrm{Ser}^{8}-\mathrm{Pro}^{7}$, and free amino acids decreased. The PCMB inhibition of $\mathrm{Arg}^{1}-$ $\mathrm{Phe}^{5} \mid \mathrm{Ser}^{6}-\mathrm{Arg}^{9}$ release was almost completely reversed by $0.5 \mathrm{mM} \mathrm{DTT}$, and that of $\mathrm{Phe}^{8}-\mathrm{Arg}^{9}, \mathrm{Ser}^{6}-\mathrm{Pro}^{7}$, and free amino acids was partially reverted, but the formation of $\mathrm{Arg}^{1}-\mathrm{Pro}^{7}$ was strongly inhibited. $\mathrm{cF}-\mathrm{Ala}-\mathrm{Ala}-\mathrm{Phe}-\mathrm{pAB}$, an inhibitor of the soluble (Chu and Orlowski, 1984) and membrane-bound (Acker et al., 1987) forms of endopeptidase 24.15 blocked the release of $\mathrm{Arg}^{1}$ $\mathrm{Phe}^{5} \mid \mathrm{Ser}^{6}-\mathrm{Arg}^{9}$ in a concentration-dependent manner (inhibition $>90 \%$ by $1 \mathrm{mM}$ inhibitor), whereas the concentration of $\mathrm{Arg}^{1}-\mathrm{Pro}^{7}$ increased up to 5.2-fold, and that of $\mathrm{Phe}^{8}-\mathrm{Arg}^{9}, \mathrm{Ser}^{6}-\mathrm{Pro}^{7}$, and free amino acids decreased as the inhibitor concentration increased. Rat brain endo-oligopeptidase A antiserum, which exhibits anticatalytic activity against endo-oligopeptidase A (Camargo et al., 1987; Toffoletto et al., 1988), strongly blocked the release of Arg ${ }^{1}-$ $\mathrm{Phe}^{5} \mid \mathrm{Ser}^{6}-\mathrm{Arg}^{9}$, increased twofold the concentration of $\mathrm{Arg}^{1}-\mathrm{Pro}^{7}$, and decreased that of $\mathrm{Phe}^{8}-\mathrm{Arg}^{9}, \mathrm{Ser}^{6}-\mathrm{Pro}^{7}$, and free amino acids. A twofold 


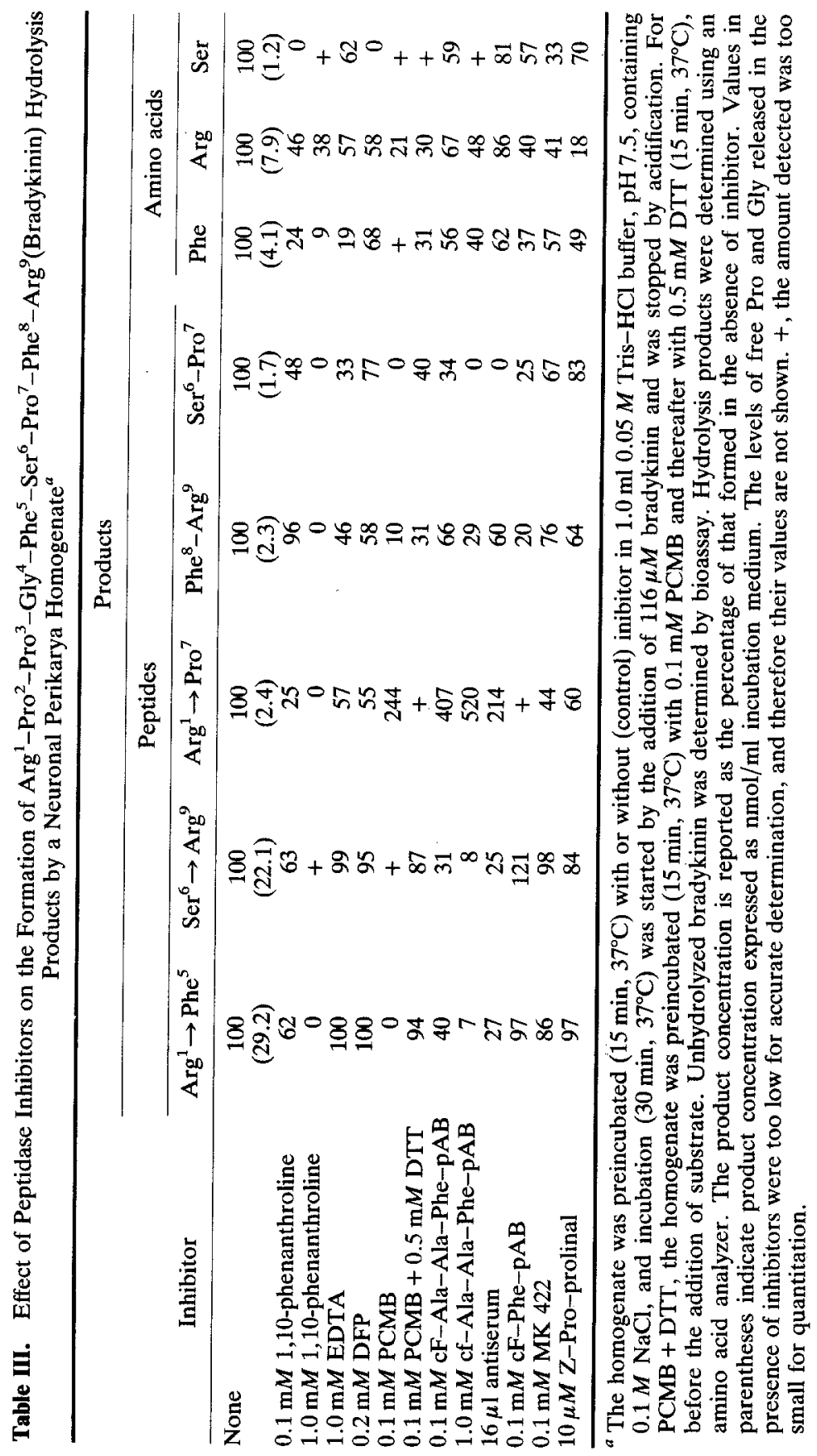


increase in antiserum concentration did not lead to a further decrease in $\mathrm{Arg}^{1}-\mathrm{Phe}^{5} \mid \mathrm{Ser}^{6}-\mathrm{Arg}^{9}$ formation. Endopeptidase 24.11 inhibitor $\mathrm{cF}-\mathrm{Phe}-\mathrm{pAB}$ $(0.1 \mathrm{~m} M)$ (Almenoff and Orlowski, 1983) strongly inhibited the formation of $\mathrm{Arg}^{1}-\mathrm{Pro}^{7}, \mathrm{Phe}^{8}-\mathrm{Arg}^{9}, \mathrm{Ser}^{6}-\mathrm{Pro}^{7}$, and free amino acids but increased $21 \%$ the $\mathrm{Ser}^{6}-\mathrm{Arg}^{9}$ concentration without affecting that of $\mathrm{Arg}^{1}-\mathrm{Phe}^{5}$. MK 422 and Z-Pro-prolinal, inhibitors of ACE (Patchett et al., 1980) and PE (Wilk and Orlowski, 1983), respectively, exhibited inhibitory effects on the release of Bk fragments which were qualitatively similar to those of cF-Phe-pAB, but less intense, except that the $\mathrm{Ser}^{6}-\mathrm{Arg}^{9}$ concentration was not affected or decreased slightly. MK $422(0.1 \mathrm{mM})$ and Z-Pro-prolinal $(10 \mu M)$ blocked 56 and $40 \%$ respectively, the formation of $\mathrm{Arg}^{1}-\mathrm{Pro}^{7}$.

\section{Effect of Peptidase Inhibitors on Ser-Pro-Phe-Arg Degradation}

$\mathrm{Ser}^{6}-\mathrm{Pro}^{7}-\mathrm{Phe}^{8}-\mathrm{Arg}^{9}$, which is one of the primary products of Bk inactivation, contains the Pro-Phe bond that was primarily cleaved in Bk (cf. Fig. 1A) and was extensively degraded by the neuronal perikarya homogenate (cf. Table 1). Therefore, we have studied the effect of peptidase inhibitors on the proteolytic processing of this tetrapeptide by the neuronal homogenate. Figure 2 , left, shows that $50 \mu M$ bestatin led to a sixfold increase in Phe-Arg release, while the phenylalanine and arginine concentrations decreased 94 and $78 \%$, respectively. These results indicate that the hydrolysis of Phe-Arg was catalyzed to a large extent by a bestatin-sensitive aminopeptidase. Since arginine release was 4.4-fold higher than that of phenylalanine in the presence of bestatin, the involvement of a carboxypeptidase in arginine release from $\mathrm{Ser}^{6}-\mathrm{Arg}^{9}$ cannot be excluded. The effect of peptidase inhibitors on Pro-Phe bond hydrolysis was studied by measuring the release of Phe-Arg from Ser $^{6}-$ Pro $^{7}-\mathrm{Phe}^{8}-\mathrm{Arg}^{9}$ in the presence of $50 \mu M$ bestatin. Figure 2, right, shows that with $50 \mu M$ bestatin, the formation of Phe-Arg from $\mathrm{Ser}^{6}-\mathrm{Arg}^{9}$ was 52,27 , and $22 \%$ inhibited by $0.1 \mathrm{mM}$ cF-Phe-pAB, $0.1 \mathrm{~m} M$ MK 422, and $0.1 \mathrm{~m} M$ Z-Pro-prolinal, respectively. A mixture of these four inhibitors, at the above concentrations, abolished the release of Phe-Arg.

\section{Characterization of the Major Bradykinin-Inactivating Endopeptidase Activity in Neuronal Perikarya}

\section{Occurrence in the Neuronal Soluble Fraction}

Table IV documents the levels of kininase and PE activites in isolated neurons. The values of kininase and PE specific activities in the neuronal perikarya homogenate corresponded to $4.2 \pm 0.56$ and $0.4 \pm 0.07$ (aveage $\pm \mathrm{SE}$; $N=9$ ), respectively, when expressed as femtomoles per minute per cell body. The yields of kininase and PE activities in the neuronal perikarya homogenate (relative to brain cortex, taken as $100 \%$ ), were $1.9 \pm 0.2 \%$ and $0.4 \pm 0.05 \%$ $(N=9)$, respectively. Kininase activity recovery was 1.7 -fold higher in the soluble $(105,000 \mathrm{~g}$ for $1 \mathrm{hr})$ than in the particulate fraction, whereas the distribution of PE activity was about the same in these fractions. These results suggest that 

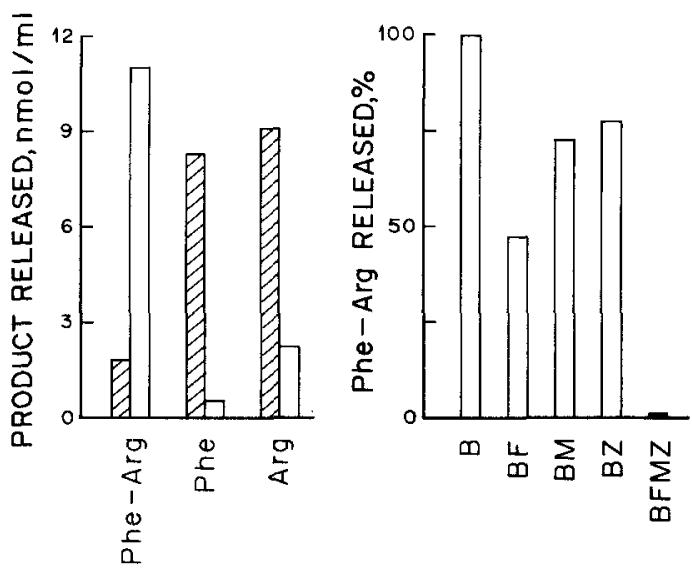

Fig. 2. Effect of peptidase inhibitors on Ser-Pro-PheArg degradation by a neuronal perikarya homogenate. The homogenate was preincubated $\left(15 \mathrm{~min}, 37^{\circ} \mathrm{C}\right)$ with or without inhibitor, in $0.05 \mathrm{M}$ Tris $-\mathrm{HCl}$ buffer, $\mathrm{pH} 7.5$, containing $0.1 \mathrm{M} \mathrm{NaCl}$, and incubation $\left(30 \mathrm{~min}, 37^{\circ} \mathrm{C}\right)$ was started by the addition of $54 \mu M$ Ser-Pro-Phe-Arg. The reaction was stopped by acidification. Degradation products were determined using an amino acid analyzer. Left: effect of bestatin on the release of Phe-Arg, Phe, and Arg from Ser-Pro-Phe-Arg. Hatched bars, no inhibitor; open bars, $50 \mu M$ bestatin. Right: effect of inhibitor combinations containing bestatin on Phe-Arg release from Ser-Pro-Phe-Arg. The amount of Phe-Arg released is reported as the percentage of that formed in the presence of $50 \mu \mathrm{M}$ bestatin alone (B), taken as $100 \%$. Inhibitor combinations used were $50 \mu M$ bestatin and $0.1 \mathrm{~m} M$ cF-Phe-pAB (F), $0.1 \mathrm{~m} M$ MK 422 (M), $0.1 \mathrm{~m} M$ Z-Pro-prolinal $(\mathrm{Z})$, and a mixture of all these inhibitors at the above concentrations (BFMZ). The amounts of free amino acids released in the presence of inhibitor combinations were too low for accurate determination, and therefore their corresponding values are not shown.

Table IV. Specific Activity and Recovery of Kininase and Prolyl Endopeptidase Activities in Neuronal Perikarya Homogenate and Homogenate-Derived Fractions ${ }^{a}$

\begin{tabular}{lccccc}
\hline & \multicolumn{2}{c}{ Kininase activity } & & \multicolumn{2}{c}{ Prolyl endopeptidase activity } \\
\cline { 2 - 3 } \cline { 5 - 6 } \multicolumn{1}{c}{ Fraction } & $\begin{array}{c}\text { Sp act } \\
\text { (nmol/min/mg protein) }\end{array}$ & $\begin{array}{c}\text { Recovery } \\
(\%)\end{array}$ & & $\begin{array}{c}\text { Sp act } \\
(\mathrm{nmol} / \mathrm{min} / \mathrm{mg} \text { protein })\end{array}$ & $\begin{array}{c}\text { Recovery } \\
(\%)\end{array}$ \\
\hline Homogenate & $5.7 \pm 0.3$ & $|100|$ & & $0.48 \pm 0.04$ & $|100|$ \\
Soluble & $5.7 \pm 0.5$ & $63 \pm 9.1$ & & $0.42 \pm 0.04$ & $52 \pm 4.5$ \\
particulare & $4.5 \pm 1$ & $37 \pm 9$ & & $0.60 \pm 0.9$ & $48 \pm 4.9$ \\
\hline
\end{tabular}

$\bar{a}$ Kininase and prolyl endopeptidase activities were measured by bioassay and fluorimetry, respectively. Recoveries are reported relative to the total recovered activity $|100 \%|$ in the soluble and particulate fractions. The yields relative to homogenate for kininase and prolyl endopeptidase activities were 121 and $119 \%$, respectively. The average values $\pm \mathrm{SE}$ of five independent determinations are reported. 
neuronal perikarya kininase activity is mainly cytosoluble, in agreement with subcellular distribution studies carried out with whole brain (Camargo and Graeff, 1969). However, kininase activity is predominantly particulate in exponentially growing neuro-2a neuroblastoma cells (DelBel et al., 1986). Neuronal PE activity is not predominantly cytosoluble, in contrast to the enzyme distribution reported using whole brain (Dresdner et al., 1982) but not to that described in neuro-2a neuroblastoma cells (DelBel et al., 1986).

A product-analysis of $\mathrm{Bk}$ degradation by soluble and particulate fractions of isolated neurons (data not shown) showed that the peptide- and amino acidproduct composition of their hydrolysates was similar to that of the parent homogenate. The $\mathrm{Phe}^{5}-\mathrm{Ser}^{6}$ bond cleavage accounted for more than $95 \%$ of $\mathrm{Bk}$ inactivation by the soluble fraction, on the basis of the relative amounts of the complementary peptide products formed. Taken together, the above results and the data in Table IV suggest that the major neuronal Bk inactivating cleavage is catalyzed by a cytosoluble endopeptidase activity which hydrolyzes the Phe $^{5}-$ Ser $^{6}$ peptide bond.

\section{Effect of Peptidase Inhibitors}

The susceptibility of the $\mathrm{Phe}^{5}-\mathrm{Ser}^{6}$ bond hydrolysis by the soluble neuronal fraction to peptidase inhibitors was studied next. Figure 3 shows that $0.5 \mathrm{mM}$ DTT did not affect the release of the complementary peptide products $\mathrm{Arg}^{1}-$ $\mathrm{Phe}^{5} \mid \mathrm{Ser}^{6}-\mathrm{Arg}^{9}$ from Bk, whereas $0.1 \mathrm{mM}$ PCMB inhibited 97\% the formation of these products. The inhibition of the $\mathrm{Phe}^{5}-\mathrm{Ser}^{6}$ bond cleavage by $0.1 \mathrm{mM}$ PCMB was surmountable by $0.5 \mathrm{~m} M$ DTT. Kininase activity in a soluble fraction dialyzed against $1.0 \mathrm{mM}$ Tris- $\mathrm{HCl}$ buffer, $\mathrm{pH} 7.0$, for $48 \mathrm{hr}$ at $4^{\circ} \mathrm{C}$, was activated by DTT in a concentration-dependent manner (data not shown). Activation was maximal (about twofold) at $0.5 \mathrm{mM}$ DTT and decreased with higher DTT concentrations. At $2.0 \mathrm{~m} M$ DTT there was essentially neither activation nor inhibition of enzyme activity. These results indicate a requirement of a thiol group for enzyme activity. DFP $(0.2 \mathrm{mM})$ did not affect the endopeptidase activity. Chelating agents differentially affected the $\mathrm{Phe}^{5}-\mathrm{Ser}^{6}$ bond cleavage. Thus, 1,10-phenanthroline exhibited a concentration-dependent inhibitory effect $(>90 \%$ inhibition by $1.0 \mathrm{~m} M)$, whereas EDTA $(1.0 \mathrm{~m} M)$ did not affect the peptidase activity. Both $\mathrm{cF}-\mathrm{Ala}-\mathrm{Ala}-\mathrm{Phe}-\mathrm{pAB}$ and antiserum inhibited the $\mathrm{Phe}^{5}-\mathrm{Ser}^{6}$ bond hydrolysis in a concentration-dependent manner, and the activity was about $90 \%$ blocked by $1.0 \mathrm{~m} M$ inhibitor and $20 \mu \mathrm{l}$ antiserum $/ \mathrm{ml}$.

\section{Effect of Metal Ions}

Since metal chelators differentially effected the $\mathrm{Phe}^{5}-\mathrm{Ser}^{6}$ bond cleavage (Table III and Fig. 3), it was not clear whether or not this enzyme activity is metal dependent. In order to address this issue, the effect of dialysis of the neuronal soluble fraction against 1,10-phenanthroline and EDTA and against chlorides of divalent cations on kininase activity was studied. PE activity was also studied because the brain enzyme has been shown not to be a metalloprotease (cf. Orlowski, 1983); it occurs in the neuronal soluble fraction (cf. Table IV) and 

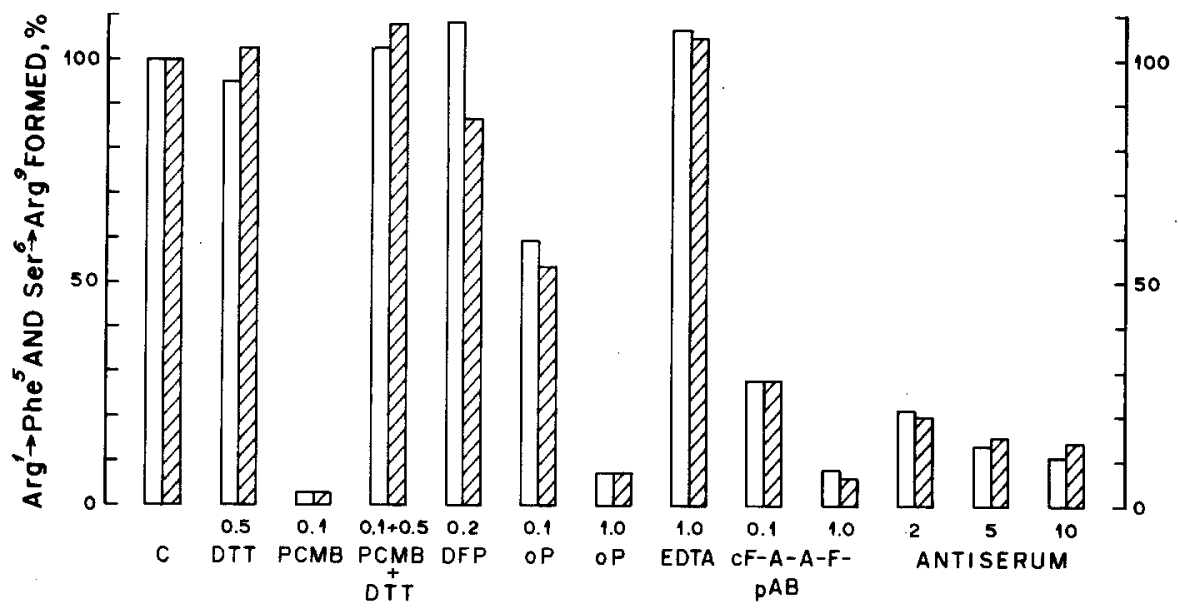

Fig. 3. Effect of peptidase inhibitors on the formation of $\operatorname{Arg}^{1}-\operatorname{Ph}^{5}(\square)$ and $\operatorname{Ser}^{6}-\operatorname{Arg}^{9}(\mathbb{Z})$ from bradykinin by a neuronal perikarya-soluble fraction. The soluble fraction was preincubated $\left(15 \mathrm{~min}, 37^{\circ} \mathrm{C}\right)$ with or without $(\mathrm{C}$, control) inhibitor, in $250 \mu \mathrm{l}$ (antiserum tubes) or $1.0 \mathrm{ml}$ $0.05 M$ Tris- $\mathrm{HCl}$ buffer, $\mathrm{pH} 7.5$, containing $0.1 \mathrm{M} \mathrm{NaCl}$, and incubation $\left(30 \mathrm{~min}, 37^{\circ} \mathrm{C}\right)$ was started by the addition of $116 \mu M$ bradykinin. The reaction was stopped by acidification. The concentrations of $\mathrm{Arg}^{1}-\mathrm{Phe}^{5}$ and $\mathrm{Ser}^{6}-\mathrm{Arg}^{9}$ released are reported as the percentage of those formed without inhibitor ( 39 and $31 \mathrm{nmol} / \mathrm{ml}$, respectively), taken as $100 \%$. Inhibitor concentrations are reported as millimolar, except for those of antiserum, which are reported as microliters of antiserum per $250 \mu \mathrm{l}$ of incubation medium. In a control experiment, it was shown that the concentrations of PCMB and DTT used here were the lowest concentrations that, upon preincubation $\left(15 \mathrm{~min}, 37^{\circ} \mathrm{C}\right)$, essentially fully inhibit $(0.1 \mathrm{mM} \mathrm{PCMB})$ and completely restore $(0.5 \mathrm{mM}$ DTT) the PCMB-inhibited kininase activity in a neuronal soluble fraction. oP, 1,10-phenanthroline; antiserum, rat brain endo-oligopeptidase A antiserum.

is affected by metal chelators (cf. Table II) similarly to the soluble endopeptidase activity which hydrolyzes the $\mathrm{Phe}^{5}-\mathrm{Ser}^{6}$ bond of Bk (cf. Fig. 3). Figure $4 \mathrm{~A}$ shows that the complete inhibition of the kininase activity in the soluble fraction by dialysis against $1.0 \mathrm{mM} 1,10$-phenanthroline was more than $95 \%$ reverted upon removal of the chelator by dialysis against $1 \mathrm{~m} M$ Tris- $\mathrm{HCl}$ buffer, $\mathrm{pH} 7.0$; these dialysis procedures led to about a $20 \%$ decrease in PE activity. In contrast (cf. Fig. 4B), kininase activity was not affected by dialysis against $1 \mathrm{~m} M$ EDTA, whereas PE activity was about $40 \%$ activated. Figure $4 \mathrm{~A}$ also shows that dialysis of the 1,10-phenanthroline-treated soluble fraction against $0.1 \mathrm{mM} \mathrm{CaCl} 2$ led to 33 and $48 \%$ activation of kininase and PE activities, respectively, whereas dialysis against $0.1 \mathrm{mMCOCl} \mathrm{CoCl}_{2}$ did not essentially affect or only slightly activated both kininase and $\mathrm{PE}$ activities. $\mathrm{ZnCl}_{2}(0.1 \mathrm{~m} M)$ led to about $55 \%$ inhibition of both enzyme activities. The removal of excess and loosely bound metal ions by dialysis against $1.0 \mathrm{~m} M$ Tris $-\mathrm{HCl}$ buffer, $\mathrm{pH} 7.0$, essentially reverted the activating and inhibitory effects of metal ions on kininase activity, whereas $\mathrm{PE}$ activation by $\mathrm{CaCl}_{2}$, but not inhibition by $\mathrm{ZnCl}_{2}$, was reverted.

Similar experiments, except that $1.0 \mathrm{~m} M$ EDTA replaced $1.0 \mathrm{~m} M 1,10$ phenanthroline, led to comparable results with respect to the metal ion effect (data not shown). Alternatively, the neuronal soluble fraction was dialyzed 


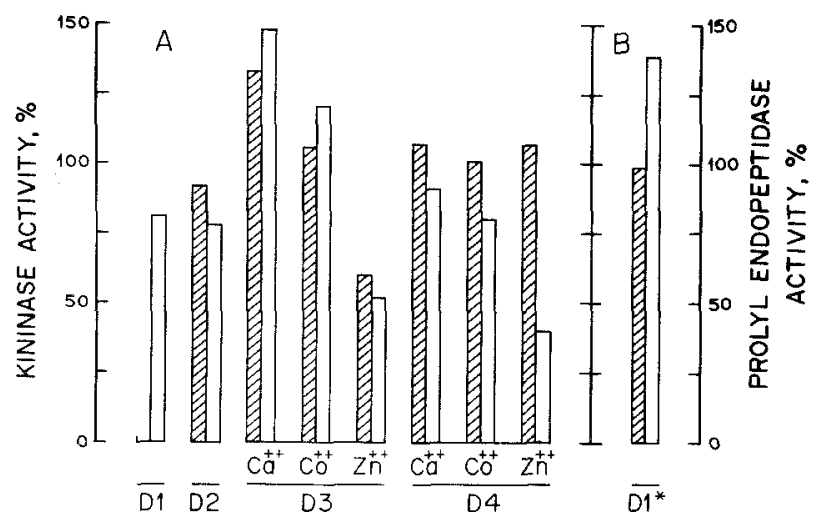

Fig. 4. Effect of dialysis against chelating agents and metal ions on kininase (田) and prolyl endopeptidase ( $\square$ ) activities in a neuronal perikarya-soluble fraction. Kininase and $P E$ activities in each dialysis-treated soluble fraction are reported relative to their specific activities in a soluble fraction dialyzed for the same time against $1.0 \mathrm{~m} M$ Tris- $\mathrm{HCl}$ buffer, $\mathrm{pH} 7.0$ (controls), which were taken as $100 \%$. Kininase and $\mathrm{PE}$ activities were determined (in the presence of 0.5 and $2.0 \mathrm{~m} M \mathrm{dTT}$, respectively) by bioassay and fluorimetry, respectively. (A) Soluble fraction $(5.0 \mathrm{ml})$ was dialyzed at $4^{\circ} \mathrm{C}$ against four changes of $500 \mathrm{ml} 1.0 \mathrm{mM} 1,10$-phenanthroline in $1.0 \mathrm{~m} M$ tris $-\mathrm{HCl}$ buffer, $\mathrm{pH} 7.0$, for $24 \mathrm{hr}$ (D1), and then against four changes of $500 \mathrm{ml} 1.0 \mathrm{mM}$ Tris- $\mathrm{HCl}$ buffer, $\mathrm{pH} 7.0$, for $24 \mathrm{hr}$ (D2). The resulting retentate was divided in three equal parts. Each part was dialyzed against two changes of $250 \mathrm{ml}$ of $0.1 \mathrm{mM} \mathrm{CaCl}$, or $0.1 \mathrm{mMCOCl}$, or $0.1 \mathrm{~m} M \mathrm{ZnCl}_{2}$ in $1.0 \mathrm{mM}$ Tris- $\mathrm{HCl}$ buffer,

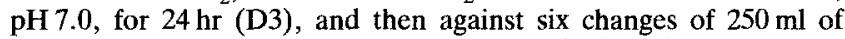

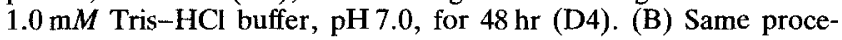
dure as for D1 in A, except that $1.0 \mathrm{~m} M$ EDTA was substituted for $1.0 \mathrm{~m} M 1,10$-phenanthroline (D1*).

against $1.0 \mathrm{~m} M$ EDTA, $\mathrm{pH} 7.0$, and then against $1.0 \mathrm{~m} M$ Tris- $\mathrm{HCl}$ buffer, $\mathrm{pH}$ 7.0. The preincubation $\left(15 \mathrm{~min}, 37^{\circ} \mathrm{C}\right)$ of this EDTA-treated fraction with $1.0 \mathrm{mM}$ $\mathrm{CaCl}_{2}$ or with $25 \mu \mathrm{M} \mathrm{ZnCl}$ led to $60 \%$ activation or $40 \%$ inhibition of kininase activity, respectively.

\section{DISCUSSION}

The present study shows that rat brain neuronal perikarya contain peptidases able to inactivate $\mathrm{Bk}$ through hydrolysis of the $\mathrm{Phe}^{5}-\mathrm{Ser}^{6}, \mathrm{Pro}^{7}-\mathrm{Phe}^{8}$, Gly ${ }^{4}-\mathrm{Phe}^{5}$, and Pro ${ }^{3}-\mathrm{Gly}^{4}$ peptide bonds (cf. Fig. 1 and Results). There is strong evidence that each of the four inactivating cleavages of $\mathrm{Bk}$ by the neuronal perikarya homogenate was catalyzed by a different peptidase, except for the $\mathrm{Pro}^{7}-\mathrm{Phe}^{8}$ bond cleavage, which appears to be catalyzed by at least three enzymes. 


\section{Neurnal Perikarya Inactivate Bradykinin Mainly Through Cleavage at the Phe ${ }^{5}-$ Ser $^{6}$ Bond by a Thiol-Endopeptidase}

The hydrolysis of $\mathrm{Bk}$ at $\mathrm{Phe}^{5}-\mathrm{Ser}^{6}$ bond by the neuronal homogenate appears to be catalyzed mainly by an endopeptidase different from the multicatalytic protease complex (Wilk and Orlowski, 1980), endopeptidase 24.15 (Orlowski et al., 1983), and endo-oligopeptidase A (Camargo et al., 1973; Carvalho and Camargo, 1981), which hydrolyze the $\mathrm{Phe}^{5}-\mathrm{Ser}^{6}$ bond. Evidence to support this is as follows. The multicatalytic protease complex is strongly inhibited by $1 \mathrm{mM} \mathrm{NaCl}$ (Wilk and Orlowski, 1980) and in our enzyme assays $100 \mathrm{~m} M \mathrm{NaCl}$ was employed. The active site-directed inhibitor of endopeptidase 25.15, cF-Ala-Ala-Phe-pAB (1 mM) (Chu and Orlowski, 1984), which does not inhibit endo-oligopeptidase A (Toffoletto et al., 1988), almost completely inhibits the $\mathrm{Phe}^{5}-\mathrm{Ser}^{6}$ bond cleavage by the neuronal homogenate. Rat brain endooligopeptidase $\mathrm{A}$ antiserum, which exhibits anticatalytic and immunoprecipitating activity against endo-oligopeptidase $\mathbf{A}$, but does not similarly affect endopeptidase 24.15 (Toffoletto et al., 1988), strongly inhibits the $\mathrm{Phe}^{5}-\mathrm{Ser}^{6}$ bond hydrolysis by the neuronal homogenate. Endo-oligopeptidase A (Camargo et al., 1987) and endopeptidase 24.15 (Orlowski et al., 1983) are strongly inhibited by both $1 \mathrm{~m} M 1,10$-phenanthroline and $1 \mathrm{~m} M$ EDTA, whereas the release of Arg $^{1}-$ Phe $^{5} \mid$ Ser $^{6}-$ Arg $^{9}$ from Bk by the neuronal homogenate is blocked by $1 \mathrm{mM}$ 1,10-phenanthroline but not by $1 \mathrm{~m} M$ EDTA (cf. Table III). The hydrolysis of the $\mathrm{Phe}^{5}-\mathrm{Ser}^{6}$ bond seems to be catalyzed by a thiol-endopeptidase (cf. Table III). Endo-oligopeptidase A (Oliveira et al., 1976; Camargo et al., 1987), but not endopeptidase 24.15 (Orlowski et al., 1983; Acker et al., 1987), has been reported as a thiol-endopeptidase.

$\mathrm{Arg}^{1}-\mathrm{Phe}^{5}$ is also a degradation product of $\mathrm{Arg}^{1}-\mathrm{Pro}^{7}$ by neuronal perikarya homogenate (cf. Table I). The inhibition of $\mathrm{Bk} \mathrm{Phe}^{5}-\mathrm{Ser}^{6}$ bond cleavage by cF-Ala-Ala-Phe-pAB, antiserum, and PCMB leads to a concomitant severalfold increase in $\mathrm{Arg}^{1}-\mathrm{Pro}^{7}$ formation (cf. Table III), suggesting that the same enzyme activity catalyzes the $\mathrm{Phe}^{5}-\mathrm{Ser}^{6}$ bond cleavage both of $\mathrm{Bk}$ and of its $\mathrm{Arg}^{1}-\mathrm{Pro}^{7}$ moiety. Endo-oligopeptidase A does not hydrolyze $\mathrm{Arg}^{1}-\mathrm{Pro}^{7}$ to an appreciable extent (Oliveira et al., 1976).

About two-thirds of the neuronal kininase activity is soluble, and more than $95 \%$ of Bk inactivation by the soluble fraction is accounted for by cleavage of the Phe $^{5}-$ Ser $^{6}$ bond (cf. Table IV and Results). Our studies on the effect of peptidase inhibitors upon the release of $\mathrm{Arg}^{1}-\mathrm{Phe}^{5} \mid \mathrm{Ser}^{6}-\mathrm{Arg}^{9}$ from $\mathrm{Bk}$ by the neuronal soluble fraction (cf. Fig. 3) provide strong evidence that a thiolendopeptidase inactivates $\mathrm{Bk}$ through cleavage of the $\mathrm{Phe}^{5}-\mathrm{Ser}^{6}$ bond and that this enzyme differs from previously described soluble peptidases which hydrolyze $\mathrm{Bk}$ at the same site. Thus, the nearly complete inhibition of the $\mathrm{Phe}^{5}-\mathrm{Ser}^{6}$ bond cleavage by $0.1 \mathrm{~m} M$ PCMB was fully reversed by $0.5 \mathrm{~m} M$ DTT, a DTT concentration that maximally activates the peptidase in a dialyzed soluble fraction. Both antiserum and cf-Ala-Ala-Phe-pAB almost completely inhibit thiol-endopeptidase activity in the neuronal perikarya soluble fraction.

The differential inhibitory effect of metal chelators on the $\mathrm{Phe}^{5}-\mathrm{Ser}^{6}$ bond 
cleavage exhibited by the neuronal perikarya homogenate (cf. Tables II and III) is also displayed by the soluble fraction (cf. Fig. 3): the Phe $^{5}-\operatorname{Ser}^{6}$ bond cleavage is blocked by $1 \mathrm{mM} 1,10$-phenanthroline, but not by $1 \mathrm{~m} M$ EDTA, as it occurs with carboxypeptidase B (Folk et al., 1960), a metalloenzyme sensitive to 1,10-pnenanthroline but not to EDTA. However, peptidases reported as nonmetalloenzymes, such as endo-oligopeptidase A (Camargo et al., 1987) and PE (Andrews et al., 1980), can be inhibited by metal chelators. By using a dialysis-based technique (Vallee et al., 1960), it was shown (cf. Fig. 4 and Results) that the inhibition of soluble neuronal kininase and PE activities by 1,10-phenanthroline is fully reversible upon removal of the chelator. In contrast to endopeptidase 24.15 (initially called soluble metalloendopeptidase), whose activity is abolished by dialysis against $1 \mathrm{~m} M$ EDTA at $\mathrm{pH} 7$ and restored by the addition of $\mathrm{Zn}^{2+}$ (Orlowski et al., 1983), the EDTA-treated neuronal soluble activity is inhibited by $\mathrm{Zn}^{2+}$. Thus, it seems clear that the thiol-endopeptidase activity described here cannot be classified as a metalloendopeptidase. However, soluble thiol-endopeptidase activity is activated by high $\mathrm{Ca}^{2+}$ concentrations, suggesting a possible role of calcium in the regulation of this activity. The evidence presented here suggests that neuronal perikarya thiol-endopeptidase activity differs from that of both endo-oligopeptidase $A$ and endopeptidase 24.15, which were reported to be two different enzymes (Camargo et al., 1987; Toffoletto et al., 1988). Our data do not permit excluding a minor contribution of endo-oligopeptidase $\mathrm{A}$ and/or endopeptidase 24.15 to the cleavage of the $\mathrm{Bk}$ Phe $^{5}-$ Ser $^{6}$ bond by neuronal perikarya.

\section{Involvement of Endopeptidase 24.11, Angiotensin-Converting Enzyme, and Prolyl Endopeptidase in BK Neuronal Inactivation}

$\mathrm{Bk}$ inactivation by the neuronal perakarya homogenate through Pro $^{7}-\mathrm{Phe}^{8}$ bond cleavage appears to be catalyzed by at least three enzymes. Evidence to support this is as follows. The formation of the complementary peptide products $\mathrm{Arg}^{1}-\mathrm{Pro}^{7} \mid \mathrm{Phe}^{8}-\mathrm{Arg}^{9}$ is partially inhibited by $1 \mathrm{mM}$ EDTA and completely blocked by $1 \mathrm{~m} M 1,10$-phenanthroline (cf. Table III), suggesting the involvement of metallopeptidase(s) in $\mathrm{Pro}^{7}-\mathrm{Phe}^{8}$ bond cleavage. The partial inhibition of this cleavage by endopeptidase 24.11 inhibitor cF-Phe-pAB (Almenoff and Orlowski, 1983; Matsas et al., 1984) and by ACE inhibitor MK 422 (Patchett et al., 1980; Matsas et al., 1984) (cf. Table III) indicates the participation of both zinc-peptidases, endopeptidase 24.11 and ACE, in $\mathrm{Pro}^{7}-\mathrm{Phe}^{8}$ bond hydrolysis. $\mathrm{PE}$ is a third enzyme seemingly to cleave the same $\mathrm{Pro}^{7}-\mathrm{Phe}^{8}$ bond, since the PE inhibitor Z-Pro-prolinal (Wilk and Orlowski, 1983) partially inhibits Bk Pro $^{7}-\mathrm{Phe}^{8}$ bond cleavage (determined by Bk-product analysis; Table III) and completely blocks PE activity (determined by fluorimetry; Table II). The serine-enzyme inhibitor DFP partially inhibits this cleavage and completely inhibits PE activity. PCMB strongly blocks $\mathrm{Pro}^{7}-\mathrm{Phe}^{8}$ bond cleavage and fully inhibits PE activity. PCMB inhibition of $\mathrm{Pro}^{7}-\mathrm{Phe}^{8}$ bond cleavage is partially reversed by DTT, which activates PE activity (Table II) and (Greene et al., 1982) but inhibits ACE (Soffer, 1981) and endopeptidase 24.11 (Almenoff and 
Orlowski, 1983). EDTA partially inhibits $\mathrm{Pro}^{7}-\mathrm{Phe}^{8}$ bond hydrolysis and does not affect PE activity, whereas 1,10-phenanthroline strongly blocks both activities. The effects of chelators on neuronal $\mathrm{Pro}^{7}-\mathrm{Phe}^{8}$ bond cleavage and PE activity are in agreement with those described for brain PE, which is not a metalloprotease (cf. reviews by Wilk, 1983; Orlowski, 1983). Neuronal soluble $\mathrm{PE}$ activity does not behave as a metalloprotease and is activated by $\mathrm{Ca}^{2+}$ (cf. Fig. 4). The activation of PE by dialysis against EDTA (cf. Fig. 4) is possibly due to the removal of inhibitory heavy metal. Indeed, some laboratories routinely include EDTA in the medium used to assay PE activity (Kato et al., 1980; Hersch, 1981). PE is a DTT-activated (Oliveira et al., 1976; Greene et al., 1982) serine-endopeptidase (Andrews et al., 1980) specifically inhibited by Z-Proprolinal (Wilk and Orlowski, 1983). The properties of PE in neuronal perikarya homogenate described here are similar to those reported for purified brain PE (cf. Wilk, 1983), except for calcium activation.

$\mathrm{Bk}$ inactivation by the neuronal perikarya homogenate through cleavage of Pro $^{3}-$ Gly $^{4}$ and Gly $^{4}-$ Phe $^{5}$ bonds seems to be catalyzed by PE and endopeptidase 24.11 , respectively, as suggested: first by the evidence that both enzymes occur in the neuronal homogenate and hydrolyze the $\mathrm{Bk} \mathrm{Pro}^{7}-\mathrm{Phe}^{8}$ bond (this report); and second, by the specificity of purified PE and endopeptidase 24.11, which hydrolyze the Bk Pro ${ }^{3}-\mathrm{Gly}^{4}$ (Orlowski et al., 1979) and Gly ${ }^{4}-\mathrm{Phe}^{5}$ (Almenoff and Orlowski, 1983) bonds, respectively, in addition to the $\mathrm{Pro}^{7}-\mathrm{Phe}^{8}$ bond cleavage.

The use of a time course of Bk-product formation to identify the sites of peptide bond cleavage, combined with a peptidase inhibitor paradigm, in which the effects of selective inhibitors can be attributed to the blockade of a given bond cleavage, leads to the model for the mechanism of Bk inactivation by rat brain neuronal perikarya proposed in Fig. 5. Primary cleavages of Bk molecule should be distinguished from secondary cleavages of inactivation products. Primary cleavage at the $\mathrm{Phe}^{5}-\mathrm{Ser}^{6}$ bond is due almost entirely to the action of a calcium-activated thiol-endopeptidase. Cleavage at the $\mathrm{Bk} \mathrm{Pro}^{7}-\mathrm{Phe}^{8}$ bond results mainly from the action of endopeptidase 24.11, ACE, and PE. The primary cleavages at $\mathrm{Pro}^{3}-\mathrm{Gly}^{4}$ and $\mathrm{Gly}^{4}-\mathrm{Phe}^{5}$ bonds appear to result from the action of $\mathrm{PE}$ and endopeptidase 24.11 , respectively. Secondary cleavages of $\mathrm{Bk}$ inactivation products are clearly demonstrated for $\mathrm{Ser}^{6}-\mathrm{Arg}^{9}$, which is converted to $\mathrm{Ser}^{6}-\mathrm{Pro}^{7}$ and $\mathrm{Phe}^{8}-\mathrm{Arg}^{9}$ by endopeptidase 24.11, ACE, and PE, and for $\mathrm{Phe}^{8}-\mathrm{Arg}^{9}$, which is hydrolyzed by a bestatin-sensitive aminopeptidase.

Enzymatic degradation has been proposed as a major mechanism for the inactivation of neuropeptides. For a peptidase to exert such a role it should fulfill some requirements, which include the ability to hydrolyze a peptide bond(s) of its potential substrate(s), leading to inactive products, and appropriate localization, among others (Lynch and Snyder, 1986; Turner et al., 1985; White et al., 1985). The ability of neuronal perikarya ACE and endopeptidase 24.11 to inactivate Bk (this report), taken together with the neurochemical properties of these membrane peptidase (Turner et al., 1985), suggests that they could play a role in Bk neuronal processing. Several possible roles have been proposed for PE such as neuropeptide processing (Martins et al., 1980; Oliveira et al., 1976, cf. Wilk, 1983), participation in intermediate steps of intracellular protein degradation 


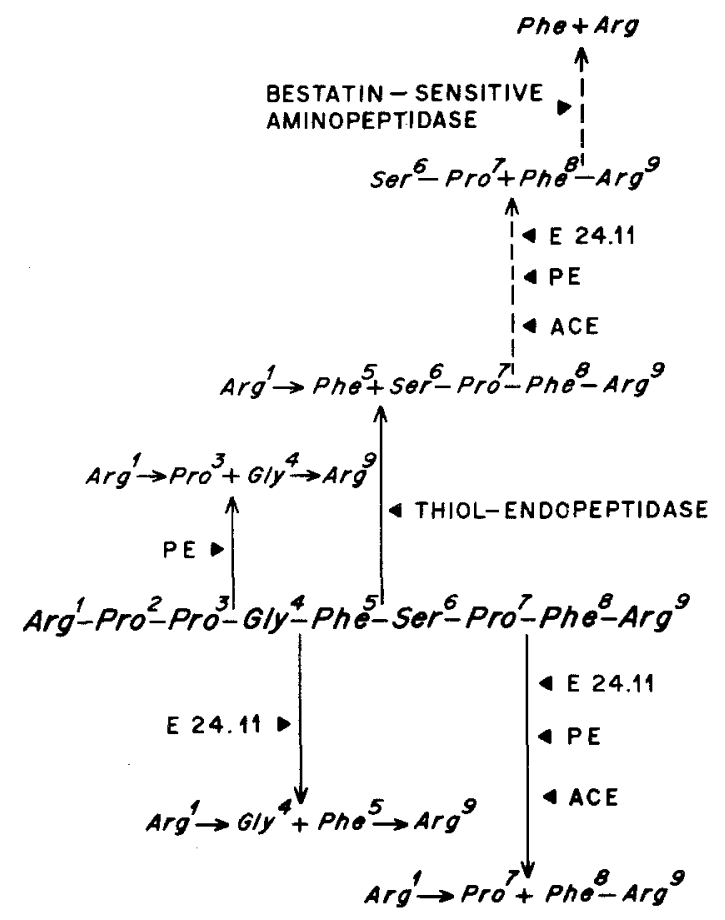

Fig. 5. Model for the mechanism of bradykinin inactivation by rat brain neuronal perikarya. Primary cleavages of bradykinin molecule are indicated by solid arrows, and secondary cleavages of inactivation products by dashed arrows. E 24.11, endopeptidase 24.11.

(Oliveira et al., 1976; Camargo et al., 1979), and participation in neural developmental processes (Kato et al., 1980; Martins and De Mello, 1985; DelBel et al., 1986; Martins et al., 1987). Peptidases that cleave the Bk Phe $^{5}-\mathrm{Ser}^{6}$ bond have been reported in adult brain (Oliveira et al., 1976; Orlowski et al., 1983; Camargo et al., 1987; MacDermott et al., 1987) and in neural systems used for developmental studies such as the chick retina (Martins and De Mello, 1985) and neuro-2a neuroblastoma cells (DelBel et al., 1986), but their similarity to the thiol-endopeptidase shown here to occur in neuronal pericarya isolated from the developing rat brain is unclear. In addition to suggesting a possible participation, if any, of PE and thiol-endopeptidase in neuronal bradykinin inactivation, this report shows that bulk isolated neurons from rat brain could be used as a model to study neuronal peptide processing.

\section{ACKNOWLEDGMENTS}

We thank Dr. M. Orlowski for the generous gift of cF-Ala-Ala-Phe-pAB and $\mathrm{cF}-\mathrm{Phe}-\mathrm{pAB}$, Drs. S. Wilk and A. C. M. Camargo for the generous gifts of Z-Pro-prolinal and endo-oligopeptidase $\mathrm{A}$ antiserum, respectively. We are 
grateful to Drs. M. U. Sampaio and M. C. O. Salgado, Escola Paulista de Medicina and Faculdade de Medicina de Ribeirão Preto da Universidade de São Paulo, respectively, for helpful review of the manuscript. We thank Dr. H. S. Pretel for helpful technical assistance and Ms. Issajuara Freire for typing the manuscript. E.A.D.B. is the recipient of FAPESP Predoctoral Fellowship 84/1968. This research was supported by Grants CNPq 30.0550-79 and 40.842885, FAPESP 84/1539-6, and FINEP 86/0849 (to A.R.M.).

\section{REFERENCES}

Acker, G. R., Molineaux, C., and Orlowski, M. (1987). Synaptosomal membrane-bound form of endopeptidase 24.15 generates Leuenkephalin from dynorphin $1-8, \alpha$ - and $\beta$-neoendorphin, and Met-enkephalin from Met-enkephalin-Arg ${ }^{6}-$ Gly $^{7}-$ Leu $^{8} . J$. Neurochem. 18:284-292.

Almenoff, J., and Orlowski, M. (1983). Membrane-bound kidney neutral metalloendopeptidase: Interaction with synthetic substrates, natural peptides and inhibitors. Biochemistry 22:590-599.

Andrews, P. C., Hines, C. M., and Dixon, J. E. (1983). Characterization of proline endopeptidase from rat brain. Biochemistry 19:590-599.

Bensadoun, A., and Weinstein, D. (1976). Assay of proteins in the presence of interfering materials. Anal. Biochem. 70:241-250.

Camargo, A. C. M., and Graeff, F. G. (1969). Subcellular distribution and properties of the bradykinin inactivation system in rabbit brain homogenates. Biochem. Pharmacol. 18:548-549.

Camargo, A. C. M., Ramalho-Pinto, F. J., and Greene, L. J. (1972). Brain peptidases: Conversion and inactivation of kinin hormones. $J$. Neurochem. 19:37-49.

Camargo, A. C. M., Shapanka, R., and Greene, L. J. (1973). Preparation, assay and partial characterization of a neutral endopeptidase from rabbit brain. Biochemistry 12:1838-1844.

Camargo, A. C. M., Martins, A. R., and Greene, L. J. (1979). Steric constraints make polypeptides resistant to hydrolysis by tissue peptidases. In Limited Proteolysis in Micro-organisms (G. N. Cohen and H. Holzer, Eds.), DEW Publication No. (NIH) 79-1591, U.S. Government Printing Office, Washington, D.C., pp. 45-48.

Camargo, A. C. M., Oliveira, E. B., Toffoletto, O., Metters, K. M., and Rossier, J. (1987). Brain endo-oligopeptidase A, a putative enkephalin converting enzyme. J. Neurochem. 48:1234-1239.

Carvalho, K. M., and Camargo, A. C. M. (1981). Purification of rabbit brain endo-oligopeptidases and preparation of anti-enzyme antibodies. Biochemistry 20:7082-7088.

Chao, J., Woodley, C., Chao, L., and Margolius, H. S. (1983). Identification of tissue kallikrein in brain and in the cell-free translation product encoded by brain mRNA. J. Biol. Chem. 258:15173-15178.

Chu, T. G., and Orlowski, M. (1984). Active site directed N-carboxymethyl peptide inhibitors of a soluble metalloendopeptidase from rat brain. Biochemistry 23:3598-3603.

Corrēa, F. M. A., Innis, R. B., Uhl, G. R, and Snyder, S. H. (1979). Bradykinin-like immunoreactive neuronal systems localized histochemically in rat brain. Proc. Natl. Acad. Sci. USA 76:1489-1493.

Croft, D. N., and Luban, M. (1965). The estimation of deoxyribonucleic acid in the presence of sialic acid: Application to analysis of human gastric washings. Biochem. J. 95:612-620.

DelBel, E. A., Gambarini, A. G., and Martins, A. R. (1986). Neuropeptide-metabolizing peptidases in Neuro-2a neuroblastoma and $\mathrm{C}_{6}$ glioma cells. J. Neurochem. 47:938-944.

Dresdner, K., Barker, L. A., Orlowski, M., and Wilk, S. (1982). Subcellular distribution of prolyl endopeptidase and cation-sensitive neutral endopeptidase in rabbit brain. $J$. Neurochem. 38:1151-1154.

Folk, J. E., Piez, K. A., Carroll, W. R., and Gladner, J. A. (1960). Carboxypeptidase B. IV. Purification and characterization of the porcine enzyme. J. Biol. Chem. 235:2272-2277.

Greene, L. J., Spadaro, A. C. C., Martins, A. R., Perussi de Jesus, W. D., and Camargo, A. C. M. (1982). Brain endo-oligopeptidase B: A post-proline cleaving enzyme that inactivates angiotensin I and II. Hypertension 4:178-184.

Hersh, L. B. (1981). Immunological, physical and chemical evidence for the identity of brain and kidney post-proline cleaving enzyme. $J$. Neurochem. 37:172-178.

Kariya, K., Yamauchi, A., Hattori, S., Tsuda, Y., and Okada, Y. (1982). The disappearance rate of 
intraventricular bradykinin in the brain of the conscious rat. Biochem. Biophys. Res. Commun. 107:1461-1466.

Kariya, K., Yamauchi, A., and Sasaki, T. (1985). Regional distribution and characterization of kinin in the CNS of the rat. J. Neurochem. 44:1892-1897.

Kato, T., Nakano, T., Kojima, K., Nagatsu, T., and Sakakibara, S. (1980). Changes in prolyl endopeptidase during maturation of rat brain and hydrolysis of substance $\mathrm{P}$ by the purified enzyme. J. Neurochem. 35:527-535.

Lowry, O. H., Rosebrough, N. J., Farr, A. L., and Randall, R. J. (1951). Protein measurement with the Folin phenol reagent. J. Biol. Chem. 193:265-275.

Lynch, D. R., and Snyder, S. H. (1986). Neuropeptides: Multiple molecular forms, metabolic pathways, and receptors. Annu. Rev. Biochem. 55:773-799.

Martins, A. R., and De Mello, F. G. (1985). Screening for neuropeptide metabolizing peptidases during the differentiation of chick embryo retina. Dev. Brain Res. 21:147-151.

Martins, A. R., Caldo, H., Coelho, H. L. L., Moreira, A. C., Antunes-Rodrigues, J., Greene, L. J., and Camargo, A. C. M. (1980). Screening for rabbit brain neuropeptide-metabolizing peptidases. Inhibition of endopeptidase B by bradykinin potentiating peptide 9a (SQ 20881). J.Neurochem. 34:100-107.

Martins, A. R., Izumi, C., Pretel, H. S., and De Mello, F. G. (1987). Ontogenesis of prolyl endopeptidase in the chick retina. Neurosci. Lett. 88:89-94.

Matsas, R., Kenny, A. J., and Turner, A. J. (1984). The metabolism of neuropeptides. Biochem. J. 223:433-440.

McDermott, J. R., Gibson, A. M., and Turner, J. D. (1987). Involvement of endopeptidase 24.15 in the inactivation of bradykinin by rat brain slices. Biochem. Biophys. Res. Commun. 146:154-158.

McPhie, P. (1971). Dialysis. In Methods in Enzymology (S. P. Colowick and N. O. Kaplan, Eds), Academic Press, New York, Vol. 22, pp. 23-26.

Oliveira, E. B., Martins, A. R., and Camargo, A. C. M. (1976). Isolation of brain endopeptidases: Influence of size and sequence of substrates structurally related to bradykinin. Biochemistry 15:1967-1974.

Orlowski, M. (1983). Pituitary endopeptidases. Mol. Cell. Biochem. 52:49-74.

Orlowski, M., Wilk, E., Pearce, S., and Wilk, S. (1979). Purification and properties of a prolyl endopeptidase from rabbit brain. $J$. Neurochem. 33:461-469.

Orlowski, M., Michaud, C., and Chu, T. G. (1983). A soluble metalloendopeptidase from rat brain. Purification of the enzyme and determination of specificity with synthetic and natural peptides. Eur. J. Biochem. 135:81-88.

Patchett, A. A., Harris, E., Tristam, E. W., Wyvrat, M. J., Wu, M. T., Taub, D., Peterson, E. R., Ikeler, T. J., tenBroeke, J., Payne, L.-G., Ondeyka, D. L., Thorsett, E. D., Greenlee, W. J., Lohr, N. S., Hoffsommer, R. D., Joshua, H., Ruyle, W. V., Rothrock, J. W., Aster, S. D., Maycock, A. L., Robinson, F. M., Hirschmman, R., Sweet, C. S., Ulm, E. H., Gross, D. M., Vassil, T. C., and Stone, C. A. (1980). A new class of angiotensin-converting enzyme inhibitors. Nature 288:280-283.

Perry, D. C., and Snyder, S. H. (1984). Identification of bradykiniń in mammalian brain. $J$. Neurochem. 43:1072-1080.

Sellinger, O. Z., Azcurra, J. M., Johnson, E., Ohlsson, W. G., and Lodin, Z. (1971). Independence of protein synthesis and drug uptake in nerve cell bodies and glial cells isolated by a new technique. Nature (New Biol.) 130:253-256.

Shikimi, T., Kema, R., Matsumoto, M., Yamahata, Y., and Miyata, S. (1973). Studies on kinin like-substances in the brain. Biochem. Pharmacol. 22:567-573.

Snyder, S. H. (1980). Brain peptides as neurotransmitters. Science 209:976-983.

Soffer, R. L. (1981). Angiotensin-converting enzyme. In Biochemical Regulation of Blood Pressure (R. L. Soffer, Ed.), John Wiley \& Sons, New York, pp. 123-164.

Spackman, D. H., Stein, W. H., and Moore, S. (1958). Automatic recording apparatus for use in chromatography of amino acids. Anal. Chem. 30:1190-1206.

Suzuki, K., Abiko, T., Endo, N., Kameyama, T., Sasaki, K., and Nabeshima, J. (1969). Biologically active synthetic fragments of bradykinin. Jpn. J. Pharmacol. 19:325-327.

Toffoletto, O., Metters, K. M., Oliveira, E. B., Camargo, A. C. M., and Rossier, J. (1988). Enkephalin is liberated from metorphamide and dynorphin A1-8 by endo-oligopeptidase A but not by metalloendopeptidase E. C. 3.4.24.15. Biochem. J. 253:35-38.

Turner, A. J., Matsas, R., and Kenny, A. J. (1985). Are there neuropeptide-specific peptidases? Biochem. Pharmacol. 34:1347-1356.

Vallee, B. L., Rupley, J. A., Coombs, T. L., and Neurath, H. (1960). The role of zinc in carboxipeptidase. J. Biol. Chem. 235:64-69. 
White, J. D., Stewart, K. D., Krause, J. E., and Mckelvy, J. F. (1985). Biochemistry of peptide-secreting neurons. Physiol. Rev. 65:553-605.

Wilk, S. (1983). Prolyl endopeptidase. Life Sci. 33:2149-2157.

Wilk, S., and Orlowski; M. (1980). Cation-sensitive neutral endopeptidase: Isolation and specificity of the bovine pituitary enzyme. J. Neurochem. 35:1172-1182.

Wilk, S., and Orlowski, M. (1983). Inhibition of rabbit brain prolyl endopeptidase by Nbenzyloxycarbonyl-prolyl-prolinal, a transition state aldehyde inhibitor. J. Neurochem. 41:69-75. 